\title{
Breast Cancer Brain Metastasis: The Potential Role of MRI Beyond Current Clinical Applications
}

This article was published in the following Dove Press journal:

Cancer Management and Research

\author{
Andria Hadjipanteli (1D ${ }^{1,2}$ \\ Paul Doolan (1D ${ }^{3}$ \\ Efthyvoulos Kyriacou (iD) ${ }^{4}$ \\ Anastasia Constantinidou (iD) ${ }^{1,2}$ \\ 'Medical School, University of Cyprus, \\ Shacolas Educational Centre for Clinical \\ Medicine, Aglantzia, Nicosia 2029, \\ Cyprus; ${ }^{2}$ Bank of Cyprus Oncology \\ Centre, Nicosia 2006, Cyprus; ${ }^{3}$ German \\ Oncology Center, Limassol, Agios \\ Athanasios 4108, Cyprus; ${ }^{4}$ Frederick \\ University, Limassol 3080, Cyprus
}

Purpose: Breast cancer brain metastasis (BCBM) represents a major clinical challenge. Can MRI help in advancements in the management of BCBM? This review discusses MRI developments and the corresponding potential advancements in BCBM management.

Methods: An exhaustive literature search was undertaken to identify studies which look into the potential of MRI in BCBM management. Seven hundred and eighty-four studies published from September 1984 to May 2020 were identified. Three topics are covered where MRI is not clinically established yet: 1) the prognosis of BCBM; 2) the screening of BC patients for $\mathrm{BCBM}$ development, and 3 ) the assessment of imaging features correlated to $\mathrm{BC}$ subtype.

Results: Thirty-six studies were considered eligible for the purposes of this review. Ongoing progress is made with the identification of different BCBM characteristics and MRI metrics that might be related to prognosis. Progress has been made with the identification of different $\mathrm{BCBM}$ characteristics, including BCBM location, degree of edema, white matter disruption, tumor edge sharpness, and temporal muscle thickness. A more accurate prediction of prognosis could lead to more suitable patient management and treatment. The use of MRI in BCBM screening of the high-risk breast cancer population remains a controversial subject. To date, there are no results from clinical trials; however, there is a rising number of relatively small studies that show concern on this subject and support BCBM screening. It is important to oncologists to be able to assess the tumor subtype non-invasively. MRI features, which have shown some correlation with subtype, include the number of tumors, location, and their distribution in the brain. Advanced tools and metrics have been produced to carry out radiological characteristics analysis on MRI images. Assessing MRI features in more detail could provide a more personalized management of patients.

Conclusion: Developments in the use of MRI have the potential to improve BCBM management.

Keywords: breast cancer brain metastasis, magnetic resonance imaging, breast cancer management

\section{Introduction}

Breast cancer $(\mathrm{BC})$ is the second most common primary tumor responsible for the development of brain metastasis (BM), following lung cancer. ${ }^{1,3}$ The prognosis of patients developing $\mathrm{BM}$ is generally poor as few patients live longer than 1 year. ${ }^{4,6}$ The difficulty of performing a biopsy in the brain, the lack of routine assessment or continued reassessment of brain metastasis via imaging of the brain, in combination with advanced image analysis, might limit progress in understanding the development of the disease. The limited understanding of the BCBM development and progression pattern, the poor quality-of-life, and the debilitating symptomatology it
Correspondence: Andria Hadjipanteli Medical School, University of Cyprus, Shacolas Educational Centre for Clinical Medicine, Palaios Dromos Lefkosias Lemesou No. 215/6, Aglantzia, Nicosia 2029, Cyprus

Tel +357-99-842794

Email hadjipanteli.andria@ucy.ac.cy 
is associated with, as well as the often inefficient treatment options make BCBM a major clinical challenge.

Imaging, a valuable tool in cancer management, is usually prompted in BCBM cases by clinical symptoms such as headache, mental status changes, nausea, and vomiting. The European Federation of Neurological Societies suggest the use of conventional magnetic resonance imaging (MRI) for the detection of lesions, in cases where there is a strong clinical suspicion for metastasis in patients with known malignancy and in patients for whom $\mathrm{CT}$ is not conclusive in determining whether a lesion is neoplastic or non-neoplastic. ${ }^{7}$ MRI can provide finer detail, localization, and characterization of brain metastases, mainly due to the high soft tissue contrast and the plethora of MRI sequences that are available to characterize intracranial lesions. Specifically, T1 and T2-weighted sequences provide anatomical details; they delineate morphologic anatomical deraignment of tissue by the tumor. Both of these sequences can be contrast enhanced, with the use of gadolinium as a contrast agent, for the detection of small metastases and for distinguishing non-neoplastic white matter disease from metastases. T2weighted images of the brain are often also fluid attenuated (FLAIR, fluid-attenuated inversion recovery) to suppress cerebrospinal fluid and detect parenchymal edema. Proton MR spectroscopy (MRS) provides information about the metabolic profile of specific regions, and can distinguish whether a brain mass is neoplastic or nonneoplastic. Another physiologic sequence which adds diagnostic information allowing for improved tumor characterization is magnetic resonance perfusion (MRP), that can be used to assess the relative cerebral blood volume (rCBV) and blood flow $(\mathrm{rCBF})$, which are both measures of vascularity. Diffusion weighted (DWI, diffusion weighted imaging) sequences assess the ease with which water molecules move around within a tissue, giving measurements of the apparent diffusion coefficient (ADC). This gives insight into cellularity (eg, tumors), cell swelling (eg, ischemia), and edema. Diffusion tensor imaging (DTI) forms an enhancement of DWI, with a bigger number of diffusion gradients and directions than DWI, which allows more advanced metrics than an average diffusion coefficient to be calculated and higher visibility.

Considering the advantages of MRI, we herein seek to further explore the potential usage of MRI in areas where its role is not clinically established yet: i) the prognosis of $\mathrm{BCBM}$; ii) the screening of $\mathrm{BC}$ patients for $\mathrm{BCBM}$ development; and iii) correlation of $\mathrm{BC}$ subtype with $\mathrm{BM}$ radiological features.

\section{Methods}

An exhaustive literature search was undertaken using the PubMed and Web of Science search engines. Using PubMed a search was made in All Fields, using the Search Term "Breast cancer brain metastasis MRI". Similarly, in the Web of Science resource. All Databases were searched using the Topic "Breast cancer brain metastasis MRI". In total, 925 studies published by the two search engines, from September 1984 to May 2020, were identified, however some were duplicates. After duplicates were removed and with the addition of 20 studies identified through sources other than PubMed and Web of Science, a total of 784 studies were considered for the purposes of this review.

Non-English studies were excluded. As a minimum the abstracts of the rest of the studies were reviewed to consider whether the study met the inclusion criteria. For studies to meet the inclusion criteria they needed to: a) be original studies (reviews were excluded); b) be patient cohort studies (animal studies, technical development, and case studies were excluded); and c) study the use of MRI alone or in comparison with other imaging modalities, in BCBM management in one of the three areas discussed above in this review. A summary of the strategy and scope, the number of identified articles and the number considered eligible for inclusion in this review are shown in Figure 1. The studies that met the inclusion criteria were categorized based on the quality rating scheme by the Oxford Centre for Evidence-based Medicine (Table 1).

\section{Results}

Out of the 784 articles identified, 36 were considered eligible for the purposes of this review. Tables 2-4 summarize the studies: Table 2 shows the role of MRI in the prognosis of BCBM; Table 3 summarizes the role of MRI in screening of BC patients for BCBM development; and iii) Table 4 presents the potential usage of MRI in the assessment of imaging features correlated to BC subtype.

\section{MRI in the Prediction of Prognosis of BCBM}

The knowledge of prognosis is valuable to patients and clinicians as it can provide direction towards the appropriate management of a patient. 


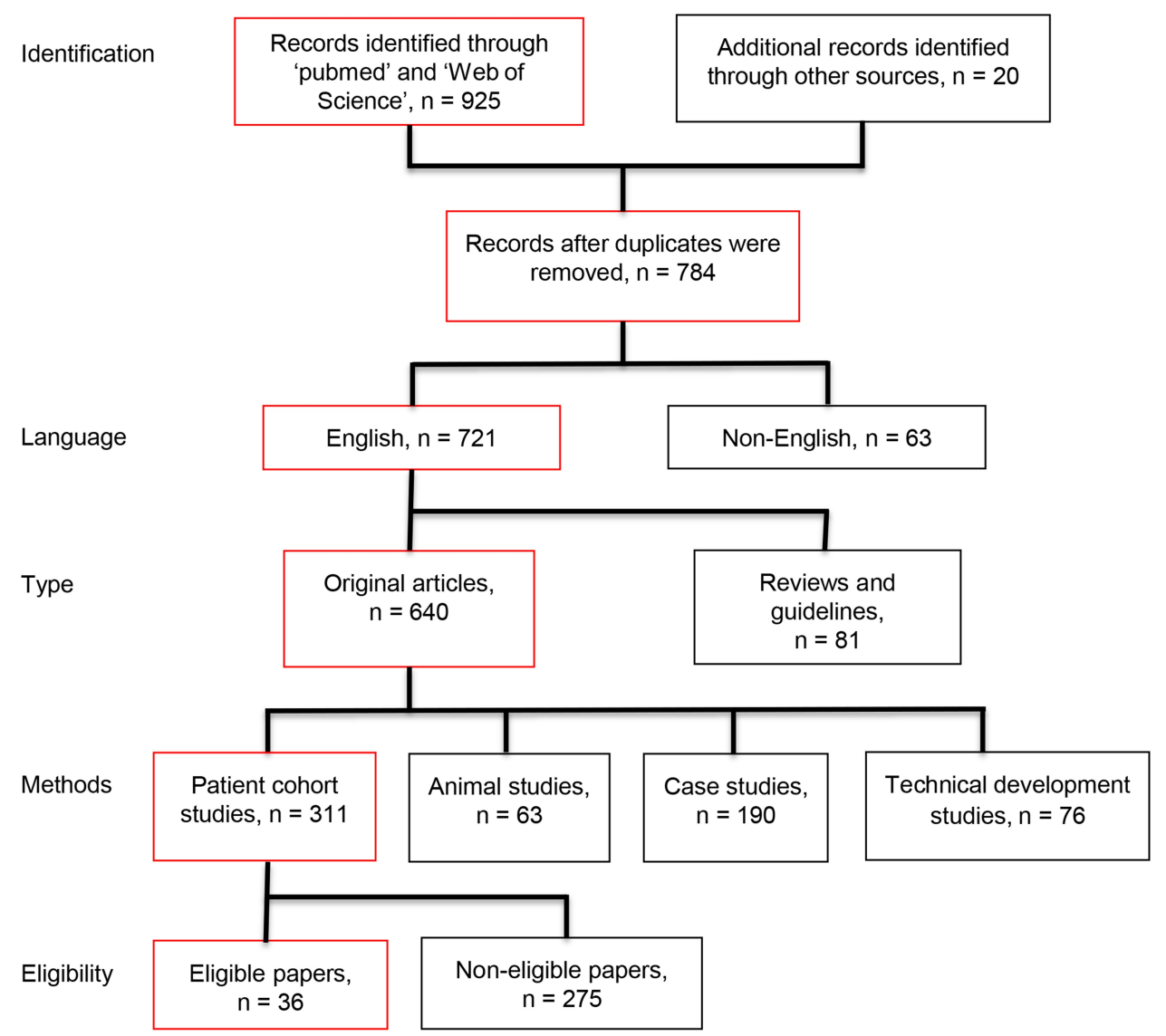

Figure I The strategy and scope of this review, the number of identified articles, and the number considered eligible for inclusion in this work. Boxes in red show the inclusion criteria.

The location of the metastasis in the brain has been shown to be associated with prognosis. Through MRI, a poor prognosis for patients with leptomeningeal disease was shown in several studies, ${ }^{8,10}$ in comparison to nonleptomeningeal. ${ }^{10}$ In one of these studies with a relatively high number (300) of BCBM patients a shorter survival was also observed in patients with metastases in the

Table I Quality Rating Scheme for Studies and Other Evidence

\begin{tabular}{|c|l|}
\hline I & $\begin{array}{l}\text { Properly powered and conducted randomized clinical trial; } \\
\text { systemic review with meta-analysis }\end{array}$ \\
\hline 2 & $\begin{array}{l}\text { Well-designed controlled trial without randomization; } \\
\text { prospective comparative cohort trial }\end{array}$ \\
\hline 3 & Case control studies; retrospective cohort study \\
\hline 4 & Case series with or without intervention; cross-sectional study \\
\hline 5 & Opinion of respected authorities; case reports \\
\hline
\end{tabular}

Notes: Oxford Centre for Evidence-based Medicine for ratings of individual studies. Adapted with permission from Oxford Centre for Evidence-Based Medicine. ${ }^{64}$ occipital lobe compared to other brain regions. ${ }^{10}$ On the contrary, in another study, it was shown that the median survival in brain metastasis patients (out of which 56\% had breast as the primary cancer site) was higher in patients in $\mathrm{BM}$ in the occipital lobe $(P=0.8)$, although not significantly so, and worse for those with brainstem lesions $(P=0.04) .{ }^{11}$ The number of BMs was shown to be a significant prognostic factor $(P<0.05$ in multivariate analysis) of overall survival, in one study with $897 \mathrm{BM}$ patients out of which 143 were BCBM patients. ${ }^{12}$

For solitary metastases, the extent of peritumoral edema on the preoperative T2-weighted conventional MR scan was shown to be related to the degree of angiogenesis, brain invasiveness, and overall survival, with reduced edema being a worse prognostic factor. ${ }^{13}$ Similarly, Berghoff et $\mathrm{al},{ }^{14}$ in a study with $379 \mathrm{BCBM}$ patients, found that peritumoral edema seen on pre-operative MRI correlated positively with the density of tumor-infiltrating lymphocytes, which in turn correlated positively with favorable overall survival times. 
Table $2 \mathrm{MRI}$ in the Prediction of Prognosis of BCBM

\begin{tabular}{|c|c|c|c|c|c|c|c|}
\hline \multirow[t]{2}{*}{ Author } & \multirow{2}{*}{$\begin{array}{l}\text { Ref. } \\
\text { No. }\end{array}$} & \multirow[t]{2}{*}{ Year } & \multirow{2}{*}{$\begin{array}{l}\text { Quality } \\
\text { Rating }\end{array}$} & \multicolumn{2}{|c|}{ Number } & \multirow[t]{2}{*}{ Aim (Relevant to This Review) } & \multirow{2}{*}{$\begin{array}{l}\text { Conclusion (Relevant to This } \\
\text { Review) }\end{array}$} \\
\hline & & & & Total & $\begin{array}{l}\text { Breast } \\
\text { ca. }\end{array}$ & & \\
\hline $\begin{array}{l}\text { Berghoff } \\
\text { et al }\end{array}$ & 17 & 2013 & 4 & 65 & 8 & To assess DWI on BM & $\begin{array}{l}\text { Preoperative DWI correlates strongly } \\
\text { and independently with OS for single } \\
\text { BM }\end{array}$ \\
\hline $\begin{array}{l}\text { Berghoff } \\
\text { et al }\end{array}$ & 14 & 2016 & 4 & 2419 & 379 & $\begin{array}{l}\text { To find correlation of edema to the } \\
\text { density of TILs }\end{array}$ & $\begin{array}{l}\text { Peritumoral edema seen MRI } \\
\text { correlates positively with the density of } \\
\text { TILs, which correlates to OS }\end{array}$ \\
\hline $\begin{array}{l}\text { Cacho-Diaz } \\
\text { et al }\end{array}$ & 11 & 2019 & 4 & 570 & 204 & $\begin{array}{l}\text { To investigate neurologic indicators as } \\
\text { prognostic markers in patients with } \\
\text { brain metastases }\end{array}$ & $\begin{array}{l}\text { BM in the brainstem were associated } \\
\text { with a poor outcome in median survival }\end{array}$ \\
\hline $\begin{array}{l}\text { Furtner } \\
\text { et al }\end{array}$ & 16 & 2017 & 4 & 435 & 188 & $\begin{array}{l}\text { Evaluate prognostic relevance of TMT } \\
\text { in BM pts }\end{array}$ & $\begin{array}{l}\text { TMT is an independent predictor of OS } \\
\text { in BCBM pts }\end{array}$ \\
\hline Gaspar et al & 19 & 1997 & I & 1200 & & $\begin{array}{l}\text { Studies if OS of brain met pts is } \\
\text { determined by treatment type or pt } \\
\text { selection for a prognostic model }\end{array}$ & $\begin{array}{l}\text { OS of brain met pts is determined by } \mathrm{pt} \\
\text { selection, and three classes of pts for } \\
\text { future studies are suggested: I) }<65 \\
\text { years and KPS } \geq 70 ; 3 \text { ) KPS }<70 ; 2 \text { ) all } \\
\text { others }\end{array}$ \\
\hline Huang et al & 22 & 2918 & 4 & 411 & & $\begin{array}{l}\text { To develop and evaluate a prognostic } \\
\text { model for patients with newly } \\
\text { diagnosed BCBM }\end{array}$ & $\begin{array}{l}\text { A nomogram for predicting } \mathrm{I} \text { - and } \\
2 \text {-year overall survival rates was } \\
\text { constructed, with a concordance index } \\
\text { of } 0.735\end{array}$ \\
\hline Hyun et al & 9 & 2016 & 4 & 519 & 96 & Analyse the clinical features of $L M$ pts & $\begin{array}{l}\text { Survival of pts with LM from BC is } \\
\text { poor ( } 3 \text { months) }\end{array}$ \\
\hline Janssen et al & 21 & 2019 & 4 & 170 & & $\begin{array}{l}\text { A prognostic tool was created for pts } \\
\text { with cerebral metastases from breast } \\
\text { cancer who had received WBRT }\end{array}$ & $\begin{array}{l}\text { Accurate results by the tool in } \\
\text { predicting death } \leq 6 \text { or survival } \geq 6 \\
\text { months for BC pts receiving WBRT }\end{array}$ \\
\hline Jo et al & 8 & 2013 & 4 & & 95 & $\begin{array}{l}\text { Analyse clinical features and outcome } \\
\text { of LM pts }\end{array}$ & $\begin{array}{l}\text { Survival of pts with LM from BC is } \\
\text { poor ( } 3.5 \text { months); Systemic chemo, in } \\
\text { addition to intratheal chemo, might give } \\
\text { OS benefit }\end{array}$ \\
\hline $\begin{array}{l}\text { Laakmann } \\
\text { et al }\end{array}$ & 10 & 2016 & 4 & & 300 & $\begin{array}{l}\text { Survival in pts with and without LM } \\
\text { disease }\end{array}$ & $\begin{array}{l}\text { Pts with LM disease had shorter } \\
\text { survival compared with patients } \\
\text { without signs of LM disease (median } \\
\text { survival } 3 \text { vs } 5 \text { months, } P=0.025 \text { ) }\end{array}$ \\
\hline Park et al & 12 & 2013 & 4 & 897 & 143 & $\begin{array}{l}\text { To analyze prognostic factors } \\
\text { (including number of lesions) on OS } \\
\text { and evaluate the role of primary } \\
\text { tumor and extracranial metastasis } \\
\text { status as a constituent factor for } \\
\text { prognostic index }\end{array}$ & $\begin{array}{l}\text { Age, KPS, number of lesions and the } \\
\text { addition of combined primary } \\
\text { tumor and ECM statuses to the } \\
\text { prognostic index can improve its } \\
\text { discrimatory ability }\end{array}$ \\
\hline $\begin{array}{l}\text { Spanberger } \\
\text { et al }\end{array}$ & 13 & 2013 & 4 & 129 & 17 & $\begin{array}{l}\text { To analyse prognostic value of extent } \\
\text { of peritumoral brain edema in pts } \\
\text { operated on for single BM }\end{array}$ & $\begin{array}{l}\text { Pts with small peritumoral edema have } \\
\text { shorter OS times }\end{array}$ \\
\hline
\end{tabular}

(Continued) 
Table 2 (Continued).

\begin{tabular}{|c|c|c|c|c|c|c|c|}
\hline \multirow[t]{2}{*}{ Author } & \multirow{2}{*}{$\begin{array}{l}\text { Ref. } \\
\text { No. }\end{array}$} & \multirow[t]{2}{*}{ Year } & \multirow{2}{*}{$\begin{array}{l}\text { Quality } \\
\text { Rating }\end{array}$} & \multicolumn{2}{|c|}{ Number } & \multirow[t]{2}{*}{ Aim (Relevant to This Review) } & \multirow{2}{*}{$\begin{array}{l}\text { Conclusion (Relevant to This } \\
\text { Review) }\end{array}$} \\
\hline & & & & Total & $\begin{array}{l}\text { Breast } \\
\text { ca. }\end{array}$ & & \\
\hline $\begin{array}{l}\text { Sperduto } \\
\text { et al }\end{array}$ & 20 & 2011 & 4 & 3940 & 400 & $\begin{array}{l}\text { To define GPA value for pts for the } \\
\text { development of a prognostic model }\end{array}$ & GPA score depends on diagnosis \\
\hline Sun et al & 15 & 2016 & 4 & & 290 & $\begin{array}{l}\text { To identify the characteristics of cystic } \\
\text { BM in a large cohost of BC pts }\end{array}$ & $\begin{array}{l}\text { Cystic BM from BC has worse } \\
\text { prognosis than solid BM }\end{array}$ \\
\hline $\begin{array}{l}\text { Zakaria } \\
\text { et al }\end{array}$ & 18 & 2018 & 3 & 26 & 4 & $\begin{array}{l}\text { To match preoperative DTI with } \\
\text { brain-tumor interface during resection } \\
\text { of BM }\end{array}$ & $\begin{array}{l}\text { DTI can be used to assess white matter } \\
\text { tract integrity, which correlates } \\
\text { positively to OS }\end{array}$ \\
\hline
\end{tabular}

MRI has also been used to assess the characteristics of cystic BM development, a special morphological type of $\mathrm{BM}$, and its risk factors to analyse the treatment and prognosis of patients with cystic BM. In a study with 35 patients with cystic BM, and 255 patients with solid BM, results of multivariate analysis have shown that cystic BM has worse prognosis $(P<0.05)$ than the more commonly observed solid BM. ${ }^{15}$

Furtner et $\mathrm{al}^{16}$ assessed the temporal muscle thickness (TMT), which is measured on routine cranial MR images, in $435 \mathrm{BM}$ patients out of which 188 had primary BC. A correlation was found between TMT and survival: for every additional $1 \mathrm{~mm}$ of baseline TMT, the BC patients had a reduced risk of death of $19 \%$.

Metrics from other MRI techniques have also been shown to be correlated to patient prognosis. Berghoff et $\mathrm{al}^{17}$ assessed DWI signal intensity and ADCs readings in 65 patients with a single $\mathrm{BCBM}$, and a high correlation was found with the overall survival of patients. Similarly, in another study, Zakaria et $\mathrm{al}^{18}$ also used DWI and showed that metastases with a sharp edge in diffusion across their border correlate to a shorter overall survival compared to those with a more diffuse edge. Information from DTI, which can detect the disruption of white matter tracts in the brain, was matched with image-guided sampling of the brain-tumor interface in 26 patients during resection of a brain metastasis (including BCBM). A lower fractional anisotropy in the peritumoral region, indicating more white matter tract disruption, was associated with longer overall survival times. It was suggested that DTI through MRI could potentially detect an active immune microenvironment and thus be used to measure susceptibility to immunotherapy.
There is an on-going effort to predict prognosis and estimate survival in brain metastasis, using MRI metrics. In summary, the location of the metastasis in the brain could be used to provide prediction of prognosis; specifically leptomeningeal disease and BCBM in the occipital lobe might be an indication of a poorer prognosis, compared to other brain regions. Edema and temporal muscle thickness were shown to be in favor of the overall survival time, while cystic BM was shown to have a worse prognosis than the solid metastasis. Finally, DWI signal intensity, ADCs, and the disruption of white matter tracts, assessed using the DTI sequence, are positively associated with prognosis, while sharp edges of the metastases are an indication of a shorter overall survival. MRI metrics such as the above could be incorporated into prognostic models, ${ }^{19,22}$ which are widely validated predictors of survival in brain metastasis patients. These models normally combine clinical information too, including age, status of the primary cancer, and extracranial disease.

\section{MRI in Screening for BCBM}

The potential of MRI as a screening tool in the management of $\mathrm{BC}$ patients at risk of developing BCBM has been debated in a small number of studies. Screening BCBM could identify BMs at an early enough stage, which could in turn guide further treatment.

A small study in 2004 assessed the benefit of a close follow-up with CT/MRI, following clinical suspicion of BCBM. ${ }^{23}$ Twenty-two patients who had been diagnosed with $\mathrm{BC}$ presented symptoms of increased intracranial pressure, but their brain CT/MRI scan did not reveal any signs of a space occupying lesion. Twelve patients had an MRI scan every 15 days; 10 patients did not, out of preference. 
Table $3 \mathrm{MRI}$ in Screening for BCBM

\begin{tabular}{|c|c|c|c|c|c|c|c|}
\hline \multirow[t]{2}{*}{ Author } & \multirow{2}{*}{$\begin{array}{l}\text { Ref. } \\
\text { No. }\end{array}$} & \multirow[t]{2}{*}{ Year } & \multirow{2}{*}{$\begin{array}{l}\text { Quality } \\
\text { Rating }\end{array}$} & \multicolumn{2}{|l|}{ Number } & \multirow{2}{*}{$\begin{array}{l}\text { Aim (Relevant to This } \\
\text { Review) }\end{array}$} & \multirow{2}{*}{$\begin{array}{l}\text { Conclusion (Relevant to This } \\
\text { Review) }\end{array}$} \\
\hline & & & & $\begin{array}{l}\text { Breast } \\
\text { ca. }\end{array}$ & Met pts & & \\
\hline Azim et al & 29 & 2018 & 4 & 2193 & 160 & $\begin{array}{l}\text { Identify incidence of BM in } \\
\text { different stages and subtypes } \\
\text { of } B C\end{array}$ & $\begin{array}{l}\text { Disease stage and biological subtypes } \\
\text { predict risk of BM }\end{array}$ \\
\hline El Zawawy & 27 & 2017 & 4 & 267 & 46 & $\begin{array}{l}\text { Retrospective review of } \\
\text { metastatic breast ca pts for } \\
\text { characteristics }\end{array}$ & $\begin{array}{l}\text { Young pts with lung mets, HER- } \\
\text { overexpression or triple -ve with DFD } \\
<2 \text { years carry highest risk for BMs }\end{array}$ \\
\hline Ghezzi et al & 31 & 1994 & I & 1320 & & $\begin{array}{l}\text { Assess impact on survival and } \\
\text { QoL in two different follow-up } \\
\text { protocols with early BC }\end{array}$ & $\begin{array}{l}\text { Routine use frequent lab tests and } \\
\text { x-rays after primary does not improve } \\
\text { OS or QoL - they are thus } \\
\text { discouraged }\end{array}$ \\
\hline Matsuo et al & 26 & 2017 & 4 & 589 & 187 & Review of outcomes of BCBM & $\begin{array}{l}\text { Early detection of BM by screening } \\
\text { MRI, followed by SRS, improved the } \\
\text { prognosis of HER2-overexpressed } \\
\text { metastatic breast ca pts }\end{array}$ \\
\hline Miller et al & 24 & 2003 & 3 & 155 & & $\begin{array}{l}\text { Assessment of the survival of } \\
\text { occult and symptomatic CNS } \\
\text { metastasis from primary BC }\end{array}$ & $\begin{array}{l}\text { Pts with CNS involvement, whether } \\
\text { occult or symptomatic, have impaired } \\
\text { survival }\end{array}$ \\
\hline $\begin{array}{l}\text { Mystakidou } \\
\text { et al }\end{array}$ & 23 & 2004 & 4 & & 22 & $\begin{array}{l}\text { Assessment of the benefit of } \\
\text { a close follow-up with CT/MRI, } \\
\text { following clinical suspicion of } \\
\text { BCBM }\end{array}$ & $\begin{array}{l}\text { An MRI screened group experienced } \\
\text { a shorter time difference between the } \\
\text { first non-radiological symptoms and } \\
\text { the first radiological symptoms, had } \\
\text { smaller tumor(s) and longer survival, } \\
\text { compared to a non-screened group }\end{array}$ \\
\hline $\begin{array}{l}\text { Niwińska } \\
\text { et al }\end{array}$ & 25 & 2010 & 3 & 80 & & $\begin{array}{l}\text { Evaluate outcome in pts with } \\
\text { occult BMs vs pts with } \\
\text { symptomatic BMs }\end{array}$ & $\begin{array}{l}\text { WBRT of early detected occult BMs in } \\
\text { HER2+ breast ca pts reduces cerebral } \\
\text { death } \times 3 \text {, but does not prolong OS }\end{array}$ \\
\hline $\begin{array}{l}\text { US National } \\
\text { Library of } \\
\text { Medicine }\end{array}$ & 32 & $\begin{array}{l}\text { On- } \\
\text { going } \\
\text { study }\end{array}$ & $\begin{array}{l}\text { On-going } \\
\text { study }\end{array}$ & $\begin{array}{l}\text { Non- } \\
\text { complete }\end{array}$ & $\begin{array}{l}\text { Non- } \\
\text { complete }\end{array}$ & $\begin{array}{l}\text { Studying the usefulness of } \\
\text { magnetic resonance imaging (MRI) } \\
\text { to screen for brain metastases }\end{array}$ & On-going study \\
\hline Ono et al & 28 & 2009 & 4 & 204 & 74 & $\begin{array}{l}\text { Find risk factors for BMs in pts } \\
\text { with HER2-overepressing breast } \\
\text { ca, who were treated with } \\
\text { trastuzumab }\end{array}$ & $\begin{array}{l}\text { Need routine screening for BMs I year } \\
\text { after start of trastuzumab in } \\
\text { recurrent } B C \text { pts } \leq 50 \text { years with liver } \\
\text { mets }\end{array}$ \\
\hline Walker et al & 30 & 2000 & 4 & 17 & 4 & $\begin{array}{l}\text { To assess the utility of whole-body } \\
\text { turbo short tau inversion } \\
\text { recovery (STIR) MRI to detect } \\
\text { metastases to liver, brain, and } \\
\text { bone }\end{array}$ & $\begin{array}{l}\text { Turbo STR whole-body MRI may } \\
\text { represent a conventional method of } \\
\text { total body screening for BC patients }\end{array}$ \\
\hline
\end{tabular}

Results have shown that the first group experienced a shorter time difference between the first non-radiological symptoms and the first radiological symptoms, had smaller tumor(s), and longer survival.
Conflicting conclusions were drawn in other studies. In a meta-analysis of clinical studies on prospective screening for $\mathrm{BCBM}$, Miller et $\mathrm{al}^{24}$ concluded on a similar survival for patients with central nervous system 
Table 4 MRI Imaging Features and Their Correlation to BC Subtype

\begin{tabular}{|c|c|c|c|c|c|c|c|c|c|}
\hline \multirow[t]{2}{*}{ Author } & \multirow{2}{*}{$\begin{array}{l}\text { Ref. } \\
\text { No. }\end{array}$} & \multirow[t]{2}{*}{ Year } & \multirow{2}{*}{$\begin{array}{l}\text { Quality } \\
\text { Rating }\end{array}$} & \multicolumn{4}{|c|}{ Number } & \multirow{2}{*}{$\begin{array}{l}\text { Aim (Relevant to } \\
\text { This Review) }\end{array}$} & \multirow{2}{*}{$\begin{array}{l}\text { Conclusion (Relevant to This } \\
\text { Review) }\end{array}$} \\
\hline & & & & Total & $\begin{array}{l}\text { Breast } \\
\text { ca. }\end{array}$ & $\begin{array}{l}\text { Met } \\
\text { pts }\end{array}$ & Mets & & \\
\hline Ahn et al & 38 & 2018 & 4 & 34 & 34 & & & $\begin{array}{l}\text { To investigate the } \\
\text { relationship between } \\
\text { DWI parameters and } \\
\text { biological markers } \\
\text { of BC }\end{array}$ & $\begin{array}{l}\text { ADC histogram analysis may have } \\
\text { a prognostic value over ER/PR status }\end{array}$ \\
\hline Bender et al & 39 & 2011 & 4 & 163 & 30 & & 118 & $\begin{array}{l}\text { Determine disease- } \\
\text { specific distribution of } \\
\text { BM }\end{array}$ & $\begin{array}{l}\text { For non-uniform distributions of } \\
\text { BMs, met-free rates might be better } \\
\text { with non-uniform irradiation }\end{array}$ \\
\hline Curtit et al & 35 & 2013 & 4 & & 489 & & & $\begin{array}{l}\text { Find intra-individual } \\
\text { correlation of ER, PR, } \\
\text { and HER2 status } \\
\text { between primary and } \\
\text { met }\end{array}$ & $\begin{array}{l}\text { Discordance in ER and PR between } \\
\text { primary and met is high, whereas } \\
\text { HER2 status remains relatively } \\
\text { constant }\end{array}$ \\
\hline Fujii et al & 34 & 2017 & 4 & & 70 & & & $\begin{array}{l}\text { To study the } \\
\text { alterations of three } \\
\text { biomarkers and Ki67 } \\
\text { index between primary } \\
\text { and mets }\end{array}$ & $\begin{array}{l}\text { ER and PR status at the time of } \\
\text { recurrence strongly impacts on OS, } \\
\text { especially if change is from positive } \\
\text { (primary) to negative (met) }\end{array}$ \\
\hline $\begin{array}{l}\text { Hoefnagel } \\
\text { et al }\end{array}$ & 36 & 2010 & 4 & & 233 & 44 & & $\begin{array}{l}\text { Study receptor } \\
\text { conversion ERa, PR, } \\
\text { HER2, for BC mets }\end{array}$ & $\begin{array}{l}\text { Receptor conversion in distant BC } \\
\text { metastases occurs }\end{array}$ \\
\hline Kyeong et al & 41 & 2017 & 4 & & 100 & & & $\begin{array}{l}\text { Find if the spatial } \\
\text { distribution of } B M \\
\text { from } B C \text { differs } \\
\text { according to their } \\
\text { biological subtypes }\end{array}$ & $\begin{array}{l}\text { BC subtypes tend to have different } \\
\text { spatial distributions of BMs }\end{array}$ \\
\hline Lower et al & 33 & 2017 & 4 & & 103 & & & $\begin{array}{l}\text { To determine } \\
\text { biomarker discordance } \\
\text { rates between first and } \\
\text { subsequent } \\
\text { metastatic } B C \text { lesions }\end{array}$ & $\begin{array}{l}\text { Continued metastatic disease } \\
\text { evolution is associated with different } \\
\text { tumor biology }\end{array}$ \\
\hline $\begin{array}{l}\text { Quattrocchi } \\
\text { et al }\end{array}$ & 40 & 2012 & 4 & & 144 & & 864 & $\begin{array}{l}\text { Find spatial distribution } \\
\text { of intra-axial BC in BC } \\
\text { and } L C \text { pts }\end{array}$ & $\begin{array}{l}\text { Distribution of BMs in BC and } L C \\
\text { patients is non-uniform }\end{array}$ \\
\hline $\begin{array}{l}\text { Uematsu } \\
\text { et al }\end{array}$ & 43 & 2009 & 4 & & 176 & & & $\begin{array}{l}\text { To compare image } \\
\text { findings of TNBM with } \\
\text { image findings of other } \\
\text { cancer subypes }\end{array}$ & $\begin{array}{l}\text { Several MRI features (tumor shape, } \\
\text { margin, internal enhancement and } \\
\text { size, as well as an intratumoral signal } \\
\text { intensity) might be used for } \\
\text { detecting TNBC }\end{array}$ \\
\hline $\begin{array}{l}\text { Williams } \\
\text { et al }\end{array}$ & 37 & 2014 & 4 & & 59 & & 59 & $\begin{array}{l}\text { To examine } \\
\text { correlations } \\
\text { between } B C \text { subtype } \\
\text { and location and } \\
\text { number of BM }\end{array}$ & $\begin{array}{l}39 \% \text { of patients with basal subtype } \\
\text { were observed to present with } \\
\text { multiple BM compared to } 61 \% \text { non- } \\
\text { basal subtypes }\end{array}$ \\
\hline
\end{tabular}

(Continued) 
Table 4 (Continued).

\begin{tabular}{|l|l|l|l|l|l|l|l|l|l|}
\hline Author & Ref. & Year & $\begin{array}{l}\text { Quality } \\
\text { No. }\end{array}$ & & \multicolumn{2}{|l|}{ Number } & \multicolumn{2}{|l|}{$\begin{array}{l}\text { Aim (Relevant to } \\
\text { This Review) }\end{array}$} & $\begin{array}{l}\text { Conclusion (Relevant to This } \\
\text { Review) }\end{array}$ \\
\cline { 3 - 8 } & & & Total & $\begin{array}{l}\text { Breast } \\
\text { ca. }\end{array}$ & $\begin{array}{l}\text { Met } \\
\text { pts }\end{array}$ & Mets & & \\
\hline Yeh et al & 42 & 2014 & 4 & & 62 & & & $\begin{array}{l}\text { Assess radiographic } \\
\text { features from a cohort } \\
\text { of BCBM pts }\end{array}$ & $\begin{array}{l}\text { Patients with BMs from TNBC have } \\
\text { distinct MRI features (cystic necrotic } \\
\text { BM) }\end{array}$ \\
\hline
\end{tabular}

involvement, whether diagnosed clinically (symptomatic) or through screening. In a prospective study on BM screening, including human epidermal growth factor receptor 2 (HER2) positive patients, it was found that even though deaths related to the central nervous system were less frequent in a BCBM MRI-screened group, there was no marked difference between the groups in the prognosis overall. $^{25}$

Some recent studies discuss the idea of high-risk BC patients undergoing BCBM screening using MRI. ${ }^{26,28}$ Young ( $\leq 50$ years) BC patients with recurrent disease, lung or liver metastasis, HER2-overexpression, or triple-negative subtype, with disease-free duration of less than 2 years, carry the highest risk for brain metastases and are considered eligible for screening. ${ }^{27,29}$

Walker et $\mathrm{al}^{30}$ assessed the utility of whole-body turbo tau inversion recovery (STIR) MRI, which employs fatsuppressed sequences, to detect metastases from the breast to other areas, including the brain. Seventeen patients of suspected metastasis, and with biopsy-proven BC, took part in this pilot study. Images were evaluated for the presence or absence of metastases and the image outcome was related to the clinical outcome at 1-year follow-up of the patient. The results suggested that STIR whole-body MRI may represent a conventional and cost-effective method of total body screening of BC patients.

Even though there is great interest, with women and healthcare professionals in favor of intensive screening and follow-up after the diagnosis of $\mathrm{BC},{ }^{31}$ it is still not clear whether women with specific BC characteristics would benefit from early screening for BMs. There is currently increased concern and the potential role of MRI in BCBM is under study as part of larger clinical trials. ${ }^{32}$

\section{MRI Imaging Features and Their Correlation to BC Subtype}

In the era of personalized medicine, treatment of metastatic $\mathrm{BC}$ is increasingly guided by its intrinsic characteristics and by its molecular drivers. Triple negative and HER2 positive constitute the two BC subtypes that most commonly tend to metastasize to the brain, although any BC subtype can do so. Interestingly, studies show that the tumor subtype may change between the primary $\mathrm{BC}$ and the metastatic cancer sites. ${ }^{33,36}$ The brain was actually found to be one of the most common sites in which there is a receptor switch. ${ }^{36}$ As such it is necessary that a biopsy is made of the recurrent or metastatic lesion for reassessment of biological features, to determine the subsequent treatment. However, brain metastatic lesions are difficult to sample and they are rarely biopsied. New methods are thus needed to define the subtype of cancer after metastasis. Efforts have been made by different groups to recognize and classify radiological features from brain MR images and identify any correlations between them and the biological behavior of the tumor.

Common features assessed in clinical practice in MR images are the number and location of BM. This information was extracted by Laakmann et $\mathrm{al}^{10}$ from $300 \mathrm{MRI}$ and CT BCBM patient images and correlations were made with the tumor-subtype; HER2+ developed cerebellar metastases more often than HER2-, whereas patients with triple-negative primary tumors more often experienced leptomeningeal disease. The number of metastases was also assessed in a different study of 59 BCBM patients; ${ }^{37}$ $39 \%$ of patients with basal subtypes were observed to present with multiple BM compared to $61 \%$ non-basal subtypes $(P=0.25)$.

The relationship between DWI parameters of BMs and biological markers of breast cancer was assessed in a study of 34 patients with BCBM. ${ }^{38}$ ADC variables did not show any statistical difference between HER2 positive and HER2 negative groups. However, it was found that ADC histogram parameters $\left(25^{\text {th }}\right.$ percentile of the ADC histogram) are highly correlated $(P<0.05)$ to the ER/PR status of breast cancer. 
Using advanced image registration methods it was shown that the spatial distribution of BCBM dominates its presence in the cerebellum, in comparison to other primary cancers. ${ }^{39,40}$ Recently and using similar techniques, Kyeong et $\mathrm{al}^{41}$ in a study with $100 \mathrm{BCBM}$ patients showed that the spatial distribution of BCBM differs according to their biological subtypes. Triple-negative cancers are evenly distributed in the brain, while HER2+ and luminal type occur mostly in the occipital lobe and cerebellum. Triple-negative was also shown to occur more often in the frontal lobe, limbic region, and parietal lobe, compared with the other two types.

Yeh et $\mathrm{al}^{42}$ performed radiographic image analysis, on $62 \mathrm{BCBM}$ images, in terms of the presence or absence of hemorrhage, restricted diffusion, enhancement, necrotic change, surrounding edema, and associated leptomeningeal disease. Cystic necrotic BM was found to occur in TNBC, in contrast to solid or mixed solid/necrotic in luminal or HER2 enriched subtype. Other MRI texture analysis features might include tumor shape, margin, internal enhancement and size, as well as an intratumoral signal intensity stronger than or almost the same as that of water of vessels on T2-weighted MR brain images. ${ }^{43}$

\section{Discussion}

The optimal management of BCBM represents an unmet clinical need. ${ }^{44,45}$ In recent years, there has been an increasing interest in developing new methods for understanding, predicting, diagnosing, and treating $\mathrm{BCBM}$ timely and effectively. In this work the potential role of MRI in three main, yet largely unexplored areas, on $\mathrm{BCBM}$ has been reviewed.

One area of interest is the use of MRI in the prediction of prognosis. Knowledge of a more accurate prognosis could help to tailor the right direction of management. Progress has been made with the identification of different $\mathrm{BCBM}$ characteristics, ${ }^{26,32}$ including $\mathrm{BCBM}$ location, ${ }^{10}$ degree of edema, ${ }^{13}$ white matter disruption, ${ }^{18}$ tumor edge sharpness, ${ }^{18}$ and TMT. ${ }^{16}$ Further development is required before these MRI metrics can be incorporated into prognostic models. Success in this area would allow a more personalized medicine approach to be introduced in BCBM management.

The use of MRI in BCBM screening of the high-risk BC population remains a controversial subject. Current breast screening guidelines, in patients with both localized and metastatic disease, do not recommend routine assessment or continued reassessment of brain metastases via imaging of the brain, due to the lack of proven benefit. ${ }^{46,48}$ Instead, any signs or symptoms of brain metastasis should be treated with a higher suspiciousness, and a lower threshold for MRI of the brain should exist. Some studies do not support the use of MRI in screening. ${ }^{24,25}$ However, at the time these studies were conducted the recommended anti-HER 2 treatments and the accuracy of MRI were different from the situation today. To date there have been no results from trials supporting the use of MRI for BCBM screening but, importantly for this argument, there are several studies which support that early identification of BMs allows for potentially less toxic approaches, such as stereotactic radiosurgery or the use of targeted systemic agents with intracranial penetration. ${ }^{49,50}$ Recently one study documented that brain metastases can grow significantly rapidly; with $30 \%$ of tumors doubling in size between diagnosis and the first day of treatment. ${ }^{51}$ Since treatment outcomes are dependent on tumor size, ${ }^{52}$ it might be important to streamline patient management processes to minimize delays in treatment initiation. Concern also exists with regards to the possibility of having similar screened BCBM incidence to non-small cell lung cancer, for which screening is recommended. ${ }^{53,54}$ Thus, several studies ${ }^{26,29}$ recommend further investigation of the usage of MRI screening in BCBM for specific high-risk groups of BC patients. In practice, MRI remains an expensive examination, which puts a limit on its easy access for routine use. Nevertheless, the degree to which early diagnoses may have an impact on important outcomes of treatment, quality-of-life, and costeffective care might warrant further investigation.

The correlation of radiological characteristics with clinical characteristics, and in particular the tumor subtype, has also recently been under investigation by several groups. The tumor subtype may switch between primary $\mathrm{BC}$ and metastatic cancer. ${ }^{33,35,55}$ A change in subtype can have an impact on survival, particularly if the change is from a primary lesion to a metastatic lesion. Monitoring the biological behavior is recommended in several studies as it can exclude secondary malignancy, which might change therapeutic strategy. Furthermore, studies suggest that more than one in five patients could undergo a different therapy, if tissue sampling was confirmed and switches of ER, PR, and HER2 were identified. ${ }^{56,57}$ Monitoring the biological behavior might benefit a patient by allowing for a novel personalized treatment strategy. The National Comprehensive Cancer Network (NCCN) recommends retesting patients with ER/PR and HER2 status in metastatic BC when the receptor status at the time of initial diagnosis is unknown, 
negative, or not over-expressed. ${ }^{58}$ It is thus important to oncologists to be able to assess the tumor subtype noninvasively, and this is where MRI might have an input. To date, MRI features, which have shown some correlation with subtype, include the number of tumors, location, ${ }^{10,59}$ and their distribution in the brain. ${ }^{39,41}$ Also, advanced tools were produced to carry out radiological characteristics analysis on MRI images, ${ }^{42,43,60}$ which allowed the identification of cancer subtype. Further studies with larger numbers of patient cases might be required before MRI can be used to assess tumor subtype. Potentially, the identification of subgroups of patients at risk of developing certain patterns of disease would enable targeted screening and treatment approaches.

This review was comprised of an extensive literature search and discussed three major main areas of interest where MRI is under consideration for advancing BCBM management. Other areas of interest which could also provide advances in BCBM management, such as the use of MRI in combination with positron emission tomography (PET), ${ }^{61,63}$ were beyond the scope of this review. All studies identified and discussed for the purposes of this review show that potential advances in the usage of MRI have promising input in BCBM management and are worth further investigation in prospective, retrospective studies and clinical trials.

\section{Conclusions}

Through an exhaustive literature search, the role of MRI in BCBM management was reviewed. The work was separated into three areas for which MRI is not clinically established: 1) the prognosis of BCBM, 2) screening of $\mathrm{BC}$ patients for $\mathrm{BCBM}$, and 3) the correlation of $\mathrm{BC}$ subtype with $\mathrm{BM}$ radiological features. Optimal and personalized patients' management could be benefited by prognostic and clinically relevant MRI metrics to identify successful treatment.

\section{Abbreviations}

ADC, apparent diffusion coefficient; BC, breast cancer; BCBM, breast cancer brain metastasi(e)s; BM, brain met; DFD, disease-free duration; DTI, diffusion tensor imaging; DWI, diffusion weighted imaging; ER, estrogen receptor status; FLAIR, fluid-attenuated inversion recovery; GPA, Graded Prognostic Assessment; HER2, human epidermal growth factor receptor 2; KPS, Karnofsky Performance Status; MRI, magnetic resonance imaging; MRS, magnetic resonance spectroscopy; MRP, magnetic resonance perfusion; LM, leptomeningeal metastasis; OS, overall survival; $\mathrm{Pt}$, patient; $\mathrm{PR}$, progesterone receptor status; QoL, quality-of-life; rCBV, relative cerebral blood volume; rCBF, relative cerebral blood flow; RT, radiotherapy; SRS, stereotactic radiosurgery; TILs, tumor-infiltrating lymphocytes; TNBC, triple negative breast cancer; TMT, temporal muscle thickness; WBRT, whole brain radiotherapy.

\section{Ethical Approval}

No ethical approval was required for the purposes of this study.

\section{Informed Consent}

No informed consent was obtained for the purposes of this study.

\section{Disclosure}

The authors report no conflicts of interest for this work.

\section{References}

1. Lee YN. (Margaret. Breast carcinoma: pattern of metastasis at autopsy. J Surg Oncol. 1983;23(3):175-180.

2. Lassman AB, DeAngelis LM. Brain metastases. Neurol Clin. 2007;25 (4):1173-1192. doi:10.1016/j.ncl.2007.07.011

3. Berghoff AS, Schur S, Füreder LM, et al. Descriptive statistical analysis of a real life cohort of 2419 patients with brain metastases of solid cancers. ESMO Open. 2016;1(2):1-9. doi:10.1136/esmoopen-2015-000024

4. Dawood S, Gonzalez-Angulo AM, Albarracin C, et al. Prognostic factors of survival in the trastuzumab era among women with breast cancer and brain metastases who receive whole brain radiotherapy: a single-institution review. Cancer. 2010;116(13):3084-3092. doi:10. $1002 /$ cncr. 25115

5. Niikura N, Hayashi N, Masuda N, et al. Treatment outcomes and prognostic factors for patients with brain metastases from breast cancer of each subtype: a multicenter retrospective analysis. Breast Cancer Res Treat. 2014;147(1):103-112. doi:10.1007/s10549-014-3090-8

6. Jang G, Lee SS, Ahn JH, et al. Clinical features and course of brain metastases in triple-negative breast cancer: comparison with human epidermal growth factor receptor 2-positive and other type at single institution in Korea. Breast Cancer Res Treat. 2011;128(1):171-177. doi:10.1007/s10549-011-1526-y

7. Soffietti R, Cornu P, Delattre JY, et al. EFNS Guidelines on diagnosis and treatment of brain metastases: report of an EFNS Task Force. Eur J Neurol. 2006;13(7):674-681. doi:10.1111/j.1468-1331.2006.01506.x

8. Jo JC, Kang MJ, Kim JE, et al. Clinical features and outcome of leptomeningeal metastasis in patients with breast cancer: a single center experience. Cancer Chemother Pharmacol. 2013;72 (1):201-207. doi:10.1007/s00280-013-2185-y

9. Hyun JW, Jeong IH, Joung AR, Cho HJ, Kim SH, Kim HJ. Leptomeningeal metastasis: clinical experience of 519 cases. Eur J Cancer. 2016;56:107-114. doi:10.1016/j.ejca.2015.12.021

10. Laakmann E, Witzel I, Scriba V, et al. Radiological patterns of brain metastases in breast cancer patients: a subproject of the german brain metastases in breast cancer (BMBC) registry. Int J Mol Sci. 2016;17 (10):10. doi:10.3390/ijms 17101615 
11. Cacho-Díaz B, Lorenzana-Mendoza NA, Chávez-Hernandez JD, González-Aguilar A, Reyes-Soto G, Herrera-Gómez Á. Clinical manifestations and location of brain metastases as prognostic markers. Curr Probl Cancer. 2019;43(4):312-323. doi:10.1016/j.currproblcancer.2018.06.002

12. Park YH, Kim TH, Jung SY, et al. Combined primary tumor and extracranial metastasis status as constituent factor of prognostic indices for predicting the overall survival in patients with brain metastases. J Korean Med Sci. 2013;28(2):205-212. doi:10.3346/ jkms.2013.28.2.205

13. Spanberger T, Berghoff AS, Dinhof C, et al. Extent of peritumoral brain edema correlates with prognosis, tumoral growth pattern, HIF1a expression and angiogenic activity in patients with single brain metastases. Clin Exp Metastasis. 2013;30(4):357-368. doi:10.1007/ s10585-012-9542-9

14. Berghoff AS, Fuchs E, Ricken G, et al. Density of tumor-infiltrating lymphocytes correlates with extent of brain edema and overall survival time in patients with brain metastases. Oncoimmunology. 2016;5 (1):1-8. doi:10.1080/2162402X.2015.1057388

15. Sun B, Huang Z, Wu S, et al. Cystic brain metastasis is associated with poor prognosis in patients with advanced breast cancer Oncotarget. 2016;7:45.

16. Furtner J, Berghoff AS, Albtoush OM, et al. Survival prediction using temporal muscle thickness measurements on cranial magnetic resonance images in patients with newly diagnosed brain metastases. Eur Radiol. 2017;27(8):3167-3173. doi:10.1007/s00330-016-4707-6

17. Berghoff AS, Spanberger T, Ilhan-Mutlu A, et al. Preoperative diffusion-weighted imaging of single brain metastases correlates with patient survival times. PLoS One. 2013;8(2):1-8. doi:10.1371/ journal.pone.0055464

18. Zakaria R, Platt-Higgins A, Rathi N, et al. T-cell densities in brain metastases are associated with patient survival times and diffusion tensor MRI changes. Cancer Res. 2018;78(3):610-616. doi:10.1158/ 0008-5472.CAN-17-1720

19. Gaspar L, Scott C, Rotman M, et al. Recursive partitioning analysis (RPA) of prognostic factors in three radiation therapy oncology group (RTOG) brain metastasis trials. Int J Radiat Oncol Biol Phys. 1997;37(4):745-751. doi:10.1016/S0360-3016(96)00619-0

20. Sperduto PW, Kased N, Roberge D, et al. Summary report on the graded prognostic assessment: an accurate and facile diagnosis-specific tool to estimate survival for patients with brain metastases. J Clin Oncol. 2012;30(4):419-425. doi:10.1200/ JCO.2011.38.0527

21. Janssen S, Hansen HC, Dziggel L, Schild SE, Rades D. A new instrument for predicting survival of patients with cerebral metastases from breast cancer developed in a homogeneously treated cohort. Radiol Oncol. 2019;53(2):219-224. doi:10.2478/raon-2019-0020

22. Huang Z, Sun B, Wu S, et al. A nomogram for predicting survival in patients with breast cancer brain metastasis. Oncol Lett. 2018;15 (5):7090-7096. doi:10.3892/o1.2018.8259

23. Mystakidou K, Kouloulias V, Tsilika E, et al. Is early recognition of radiologically silent brain metastasis from breast cancer beneficial? A retrospective study of 22 cases. Breast Cancer. 2004;11 (3):276-281. doi:10.1007/BF02984549

24. Miller KD, Weathers T, Haney LG, et al. Occult central nervous system involvement in patients with metastatic breast cancer: prevalence, predictive factors and impact on overall survival. Ann Oncol. 2003;14(7):1072-1077. doi:10.1093/annonc/mdg300

25. Niwińska A, Tacikowska M, Murawska M. The effect of early detection of occult brain metastases in HER2-positive breast cancer patients on survival and cause of death. Int J Radiat Oncol Biol Phys. 2010;77(4):1134-1139. doi:10.1016/j.ijrobp.2009.06.030

26. Matsuo S, Watanabe J, Mitsuya K, Hayashi N, Nakasu Y, Hayashi M. Brain metastasis in patients with metastatic breast cancer in the real world: a single-institution, retrospective review of 12-year follow-up. Breast Cancer Res Treat. 2017;162(1):169-179. doi:10.1007/s10549017-4107-x
27. El Zawawy SF. 2360 PRMONARCH 3: abemaciclib as initial therapy for patients with HR+/HER2- advanced breast cancer. Ann Oncol. 2017;28(suppl_5):1339-1345. doi:10.1093/annonc/ mdx 075

28. Ono M, Ando M, Yunokawa M, et al. Brain metastases in patients who receive trastuzumab-containing chemotherapy for HER2-overexpressing metastatic breast cancer. Int J Clin Oncol. 2009;14(1):48-52. doi:10.1007/s10147-008-0797-8

29. Azim HA, Abdel-Malek R, Kassem L. Predicting brain metastasis in breast cancer patients: stage versus biology. Clin Breast Cancer. 2018;18(2):e187-95. doi:10.1016/j.clbc.2017.08.004

30. Walker R, Kessar P, Blanchard R, et al. Turbo STIR magnetic resonance imaging as a whole-body screening tool for metastases in patients with breast carcinoma: preliminary clinical experience. J Magn Reson Imaging. 2000;11(4):343-350. doi:10.1002/(SICI) 1522-2586(200004)11:4<343::AID-JMRI1>3.0.CO;2-P

31. Ghezzi P, Magnanini S, Rinaldini M, et al. Impact of follow-up testing on survival and health-related quality of life in breast cancer patients. JAMA. 1994;271(20):1587-1592. doi:10.1001/jama.1994. 03510440047031

32. U.S. National Library of Medicine [Internet]: Maryland (USA): National Institutes of Health. Screening magnetic resonance imaging of the brain in patients with breast cancer. 2000 - Identifier NCT04030507. Bethesda, Maryland (United States; July 2019. Available from https://clinicaltrials.gov/ct2/show. Accessed July 31, 2020.

33. Lower EE, Khan S, Kennedy D, Baughman RP. Discordance of the estrogen receptor and HER-2/neu in breast cancer from primary lesion to first and second metastatic site. Breast Cancer Targets Ther. 2017;9:515-520. doi:10.2147/BCTT.S137709

34. Fujii K, Watanabe R, Ando T, et al. Alterations in three biomarkers (estrogen receptor, progesterone receptor and human epidermal growth factor 2) and the Ki67 index between primary and metastatic breast cancer lesions. Biomed Rep. 2017;535-542.

35. Curtit E, Nerich V, Mansi L, et al. Discordances in estrogen receptor status, progesterone receptor status, and HER2 status between primary breast cancer and metastasis. Oncologist. 2013;18(6):667-674. doi:10.1634/theoncologist.2012-0350

36. Hoefnagel LDC, van de Vijver MJ, van Slooten HJ, et al. Receptor conversion in distant breast cancer metastases. Breast Cancer Res. 2010;12:5. doi:10.1186/bcr2645

37. Williams N, Varadan V, Vadodkar A, et al. Intrinsic subtypes and MRI patterns in brain metastasis associated with breast cancer. Thirty-Seventh Annual CTRC-AACR San Antonio Breast Cancer Symposium. 2014.

38. Ahn SJ, Park M, Bang S, et al. Apparent diffusion coefficient histogram in breast cancer brain metastases may predict their biological subtype and progression. Sci Rep. 2018;8(1):1-7. doi:10.1038/ s41598-018-28315-y

39. Bender ET, Tomé WA. Distribution of brain metastases: implications for non-uniform dose prescriptions. $B r \quad J$ Radiol. 2011;84 (1003):649-658. doi:10.1259/bjr/30173406

40. Quattrocchi CC, Errante Y, Gaudino C, et al. Spatial brain distribution of intra-axial metastatic lesions in breast and lung cancer patients. $J$ Neurooncol. 2012;110(1):79-87. doi:10.1007/s11060012-0937-x

41. Kyeong S, Jin Cha Y, Gwe Ahn S, Hyun Suh S, Ju Son E, Jun Ahn S. Subtypes of breast cancer show different spatial distributions of brain metastases. PLoS One. 2017;12(11):1-10. doi:10.1371/journal. pone. 0188542

42. Yeh RH, Yu JC, Chu CH, et al. Distinct MR imaging features of triple-negative breast cancer with brain metastasis. J Neuroimaging. 2015;25(3):474-481. doi:10.1111/jon.12149

43. Uematsu T, Kasami M, Yuen S. Triple-negative breast cancer: correlation between MR imaging and pathologic findings. Radiology. 2009;250(3):638-647. doi:10.1148/radiol.2503081054 
44. Rostami R, Mittal S, Rostami P, Tavassoli F, Jabbari B. Brain metastasis in breast cancer: a comprehensive literature review. $J$ Neurooncol. 2016;127(3):407-414. doi:10.1007/s11060-016-2075-3

45. Schouten LJ, Rutten J, Huveneers HAM, Twijnstra A. Incidence of brain metastases in a cohort of patients with carcinoma of the breast, colon, kidney, and lung and melanoma. Cancer. 2002;94 (10):2698-2705. doi:10.1002/cncr.10541

46. Ramakrishna N, Temin S, Chandarlapaty S, et al. Recommendations on disease management for patients with advanced human epidermal growth factor receptor 2-positive breast cancer and brain metastases: american Society of Clinical Oncology clinical practice guideline. J Clin Oncol. 2014;32(19):2100-2108. doi:10.1200/JCO.2013.54.0955

47. Cardoso F, Harbeck N, Fallowfield L, Kyriakides S, Senkus E. Locally recurrent or metastatic breast cancer: ESMO clinical practice guidelines for diagnosis, treatment and follow-up. Ann Oncol. 2012;23((SUPPL):7. doi:10.1093/annonc/mds232

48. Huynh PT, Lemeshko SV, Mahoney MC, et al. ACR Appropriateness Criteria ${ }^{\circledR}$ Stage I breast carcinoma. J Am Coll Radiol. 2016;13(11): e53-7. doi:10.1016/j.jacr.2016.09.024

49. Brown PD, Jaeckle K, Ballman KV, et al. Effect of radiosurgery alone vs radiosurgery with whole brain radiation therapy on cognitive function in patients with 1 to 3 brain metastases: a randomized clinical trial. JAMA. 2016;316(4):401-409. doi:10.1001/jama.2016.9839

50. Metro G, Foglietta J, Russillo M, et al. Clinical outcome of patients with brain metastases from HER2-positive breast cancer treated with lapatinib and capecitabine. Ann Oncol. 2011;22(3):625-630. doi:10.1093/annonc/mdq434

51. Plunkett RJ, Barone TA, Brady WE, Attwood KM, Prasad D.Do brain mets grow while you wait? A volumetric natural history assessment of brain metastases from time of diagnosis to gamma knife treatment. J Clin Neurosci.2019;68:117-122. doi:10.1016/j.jocn.2019.07.019

52. Shaw E, Scott C, Souhami L, et al. Single dose radiosurgical treatment of recurrent previously irradiated primary brain tumors and brain metastases: final report of RTOG protocol 90-05. Int J Radiat Oncol Biol Phys. 1999;47(2):291-298. doi:10.1016/S0360-3016(99)00507-6

53. Kim SY, Kim JS, Park HS, et al. Screening of brain metastasis with limited Magnetic Resonance Imaging (MRI): clinical implications of using limited brain MRI during initial staging for non-small cell lung cancer patients. J Korean Med Sci. 2005;20(1):121-126. doi:10.3346/ jkms.2005.20.1.121

54. Li PC, Cagney DN, Martin A, Weiss SE, Alexander B, Aizer AA. Brain metastases in patients with breast cancer versus non-small cell lung cancer: comparison of an unscreened versus a screened population. Int J Radiat Oncol. 2017;99(2):E30.
55. Kuwabara T, Yoshikawa K. Physical performance testing of digital breast tomosynthesis. Proc SPIE Med Imaging. 2015.

56. Thompson AM, Jordan LB, Quinlan P, et al. Prospective comparison of switches in biomarker status between primary and recurrent breast cancer: the Breast Recurrence In Tissues Study (BRITS). Breast Cancer Res. 2010;12:6. doi:10.1186/bcr2771

57. Simmons C, Miller N, Geddie W, et al. Does confirmatory tumor biopsy alter the management of breast cancer patients with distant metastases? Ann Oncol. 2009;20(9):1499-1504. doi:10.1093/annonc/ mdp028

58. Lindström LS, Karlsson E, Wilking UM, et al. Clinically used breast cancer markers such as estrogen receptor, progesterone receptor, and human epidermal growth factor receptor 2 are unstable throughout tumor progression. $J$ Clin Oncol. 2012;30(21):2601-2608. doi:10.1200/JCO.2011.37.2482

59. Hengel K, Sidhu G, Choi J, et al. Attributes of brain metastases from breast and lung cancer. Int J Clin Oncol. 2013;18(3):396-401. doi:10.1007/s10147-012-0392-x

60. Béresová M, Larroza A, Arana E, Varga J, Balkay L, Moratal D. 2D and 3D texture analysis to differentiate brain metastases on MR images: proceed with caution. Magn Reson Mater Physics Biol Med. 2018;31(2):285-294. doi:10.1007/s10334-017-0653-9

61. Zakaria R, Das K, Bhojak M, Radon M, Walker C, Jenkinson MD. The role of magnetic resonance imaging in the management of brain metastases: diagnosis to prognosis. Cancer Imaging. 2014;14(1):1-8. doi:10.1186/1470-7330-14-1

62. Taneja S, Jena A, Goel R, Sarin R, Kaul S. Simultaneous whole-body 18F-FDG PET-MRI in primary staging of breast cancer: A pilot study. Eur J Radiol. 2014;83(12):2231-2239. doi:10.1016/j.ejrad.2014.09.008

63. Schmidt GP, Baur-Melnyk A, Haug A, et al. Comprehensive imaging of tumor recurrence in breast cancer patients using whole-body MRI at 1.5 and 3 T compared to FDG-PET-CT. Eur J Radiol. 2008;65 (1):47-58. doi:10.1016/j.ejrad.2007.10.021

64. Oxford Centre for Evidence-Based Medicine. OCEBM Levels of Evidence Working Group. The Oxford Levels of Evidence 2. Available from: https://www.cebm.ox.ac.uk/resources/levels-of-evi dence/ocebm-levels-of-evidence. Accessed September 22, 2020

\section{Publish your work in this journal}

Cancer Management and Research is an international, peer-reviewed open access journal focusing on cancer research and the optimal use of preventative and integrated treatment interventions to achieve improved outcomes, enhanced survival and quality of life for the cancer patient.
The manuscript management system is completely online and includes a very quick and fair peer-review system, which is all easy to use. Visit http://www.dovepress.com/testimonials.php to read real quotes from published authors. 